\title{
Rheumatoid arthritis patients express a skewed repertoire of polyclonal, hypomutated B-cell receptors
}

Graeme J.M. Cowan ${ }^{1}$, Katherine Miles ${ }^{2}$, Lorenzo Capitani ${ }^{1}$, Sophie S.B. Giguere ${ }^{1}$, Hanna Johnsson $^{3}$, Carl Goodyear ${ }^{3}$, lain B. Mclnnes ${ }^{3}$, Scottish Early Rheumatoid Arthritis Inception cohort Investigators ${ }^{5}$, Steffen Breusch ${ }^{4}$, David Gray ${ }^{1}$, Mohini Gray ${ }^{2}$.

Author affiliations: ${ }^{1}$ Institute of Immunology and Infection Research, Ashworth Laboratories, Charlotte Auerbach Road, The King's Buildings, The University of Edinburgh, EH9 3FL, Edinburgh, Scotland, ${ }^{2} \mathrm{MRC} /$ University of Edinburgh Centre for Inflammation Research, The Queen's Medical Research Institute, 47 Little France Crescent, Edinburgh EH16 4TJ, ${ }^{3}$ University of Glasgow, Institute of Infection, Immunity and Inflammation, College of Medical, Veterinary and Life Sciences, Sir Graeme Davies Building, 120 University Place, Glasgow, G12 8TA, ${ }^{4}$ Orthopaedic Unit, Royal Infirmary of Edinburgh, 51 Little France Cres, Edinburgh EH16 4SA. ${ }^{5}$ See supplementary file for list of investigators.

${ }^{*}$ Corresponding Author:

Mohini Gray

MRC/University of Edinburgh Centre for Inflammation Research

The Queen's Medical Research Institute,

47 Little France Crescent,

Edinburgh EH16 4TJ

Tel 0131 242-6684

mohini.gray@ed.ac.uk

Abbreviations

BCR - B cell receptor

DMARD - Disease modifying anti-rheumatic drug

$\mathrm{V}_{\mathrm{H}}$ - variable portion of the heavy chain

BCDT -B cell depletion therapy

ACPA - anti citrullinated protein antibodies

RF- rheumatoid factor

NGS - next generation sequencing

PBMC - peripheral blood mononuclear cells

ERA - early rheumatoid arthritis

ESRA - established RA

CDR - complementarity determining region

SHM - somatic hypermutation 
AID - activation-induced cytidine deaminase

GC - germinal centre

FR - framework region

CS - class-switching

\section{Conflict of interest statement}

The authors have declared that no conflict of interest exists.

\section{Abstract \\ Objectives}

The success of $B$ cell depletion therapy in rheumatoid arthritis (RA) therapy testifies to their importance in disease pathogenesis, but the precise B cells mediating this are unclear. For example, it is unknown if RA patients predominantly express a limited number of circulating clonally expanded populations of B cells with highly mutated B cell antigen receptors (BCRs) that would constitute a shared antigen driven response.

\section{Methods}

To address this, we have undertaken the largest study to date utilising next generation sequencing (NGS), to identify the full length of the peripheral blood BCR sequences from the antigen-binding heavy chain. Between 25,000 to 200,000 BCR sequences per patient were analysed from 127 newly diagnosed RA patients, 16 heathy controls, 16 RA patients with established disease and 8 paired blood and synovial samples. This was complemented with B cell subset analysis from an additional 64 RA patients and 22 healthy controls.

\section{Results}

RA patients expressed a significantly higher percentage of circulating poorly mutated polyclonal $\mathrm{lgG}^{+v e}$ variable heavy (lgG-Vh) BCR sequences, both at the time of diagnosis and following treatment. These sequences resided predominantly within TNF-alpha secreting $\lg \mathrm{G}^{+\mathrm{ve}} \mathrm{CD} 27^{-\mathrm{ve}} \mathrm{B}$ cells, that were expanded in RA peripheral blood and enriched in the rheumatoid synovium. Surprisingly, peripheral and synovial B cell repertoires of RA patients are quite distinct, sharing very few IgG sequences.

\section{Conclusions}

This is the first report to conclusively establish that a substantial component of the peripheral $B$ cell repertoire in RA consists of polyclonal hypomutated $\operatorname{lgG}^{+v e} B C R$ s that may play a critical role in driving an autoimmune mediated inflammation.

Key words

Rheumatoid arthritis 


\section{B cell receptor \\ Inflammation \\ Pathogenesis \\ B cell depletion}

\section{Funding}

This work was made possible by grants from the Wellcome Trust to Mohini Gray (WT109705MA) and David Gray (University of Edinburgh-ISSF ). 


\section{Introduction}

Rheumatoid arthritis (RA) is the commonest autoimmune inflammatory arthritis, affecting up to $1 \%$ of the world's population $(1,2)$. It is characterised by chronic systemic inflammation that targets the synovial joints leading to progressive joint damage and disability. Whilst pathogenesis is incompletely understood, the pivotal role of $B$ cells is supported by the efficacy of $B$ cell depletion therapy (BCDT) in the majority of treated patients (2-4). Auto-antibodies binding to post-translationally modified epitopes [e.g. citrullinated protein antigens (ACPA)] or the constant region of other immunoglobulins [called rheumatoid factor (RF)] (5), augment the generation of immune complexes. However good clinical responses to BCDT do not always correlate with a reduction in the titre of $\operatorname{ACPA}(6,7)$, implying that ACPA may originate from long lived plasma cells, that are not targeted by anti-CD20 antibody therapy (8). The promotion of inflammation by self reactive $B$ cells is likely to extend well beyond these specifcities. Understanding this would lead to more specific RA therapies and the hope of an eventual cure.

The advent of accessible, high throughput sequencing technologies has enabled formal evaluation of differences between the $B$ cell repertoire of healthy and diseased individuals. To date, studies characterising the $B$ cell repertoire of RA patients have been limited in number, sample size or sequencing depth (9). An understanding of the expressed BCR repertoires in RA patients would provide a more complete understanding of disease pathogenesis. We hypothesized that RA patients would have expansions of circulating pathogenic $B$ cells at diagnosis, that could also be detected as a conserved BCR signature in established disease. Utilising next generation sequencing (NGS) of peripheral blood and synovial B cells, we sequenced the repertoire of expressed BCRs, focusing on the main antigen binding IgG variable heavy (lgG-Vh) region. We assessed 127 newly diagnosed RA patients, 16 patients with established RA and 8 paired blood and synovial samples. In addition we phenotyped B cells from an additional 64 RA patients and 22 healthy controls. Surprisingly, RA patients expressed significantly more $\lg ^{+v e} B C R$ sequences with fewer than five mutations (which we refer to hereafter as hypomutated or $\left.\lg G^{\text {hypoM }}\right)$. The hypomutated Vh-lgG BCRs were polyclonal and originated from TNF-alpha secreting $\operatorname{lgG}{ }^{+v e} C D 27^{-v e}$ cells, which were significantly increased in the circulation. Unexpectedly, we detected a minimal sharing of sequences either between patients or between the synovium and peripheral blood of the same patient. 


\section{Materials and Methods}

\section{Ethical review and donor selection criteria}

The use of human samples for cohorts 1, 3 and 4 was approved by the South East Scotland Bioresource NHS Ethical Review Board (Ref 15/ES/0094). Ethical permission to collect samples donated to the SERA inception (cohort 2) was approved by the West of Scotland Local Research Ethics Committee (Ref 10/S0703/4) as previously described(10). Informed consent was obtained from all study participants prior to sample collection. Patient cohorts are described in supplementary Tables 1-4.

\section{Patient and Public Involvement}

Patients were not involved in the design of this study. Patients will be informed of the results of the study through the activities of the Centre for Inflammation Research public engagement events (https://www.edweb.ed.ac.uk/inflammation-research/information-public) and patient groups, including NRAS.

\section{Flow Cytometry \& FACS sorting}

Lymphocytes were stained in PBS with $1 \%$ FCS for 20 minutes at $4{ }^{\circ} \mathrm{C}$. A BD Aria II was used for flow sorting and a BD LSRII was used to collect data. All analysis was performed using FlowJo software. Debris and dead cells were excluded using FSC-SSC. Doublets were excluded using both FSC and SSC singlet gating. A list of antibody reagents is shown in supplementary table 5 . Intracellular staining was performed, following stimulation (for $4.5 \mathrm{~h}$ ) with PMA [Sigma $(20 \mathrm{ng} / \mathrm{ml})]$ \& Ionomycin [Sigma $(1 \mu \mathrm{g} / \mathrm{ml})]$. After $1 \mathrm{~h}$ of stimulation Brefeldin A [Sigma $(1 \mu \mathrm{g} / \mathrm{ml})$ ] was added for the remaining $3.5 \mathrm{hrs}$. Surface staining was performed before fixation and permeabilisation using a Cytofix/Cytoperm kit (BD Biosciences).

\section{Cell purification}

Peripheral blood mononuclear cells (PBMC) were prepared from citrated blood samples using Ficoll ${ }^{\circledR}$ Paque Plus density centrifugation (GE Healthcare). Synovial tissue was digested for $2 \mathrm{~h}$ at $37{ }^{\circ} \mathrm{C}$ in $1 \mathrm{mg} \mathrm{ml}^{-1}$ Collagenase 1 (Sigma-Aldrich). PBMC and synovial tissue were enriched for B-cells using either anti-CD19 or anti-CD20 magnetic beads (Miltenyi Biotech) (see Supplementary table 6).

\section{B cell repertoire sequencing}

Supplementary table 4 specifies the individual amplification strategies employed for samples. mRNA was purified using mRNA direct kit (Life Technologies), or total RNA was purified using either a Direct-zol total RNA kit (Zymo Research) or a Paxgene blood RNA kit (Qiagen). The amplification protocol, immune repertoire analysis and $B$ cell clone lineage tree construction is provided in the online supplementary methods. 


\section{Statistical analysis and data visualisation}

Before performing inferential statistical tests, data were assessed for conformity to the assumptions of the test used. The assumption of normality of data was visually assessed using the $\mathrm{Q}-\mathrm{Q}$ plot method, generated using the StatsModels Python package. Prism 6.0 (GraphPad Software Inc.) or the scipy.stats Python package (11) was used to perform all Student's T tests, Mann-Whitney and Kruskal-Wallis non-parametric tests and Dunn's post hoc test was run using the scikit-posthocs module (12). For analyses involving multiple pairwise comparisons, p-value adjustment was performed using the Holm-Šídák method (13). Two-tailed p-values are given in all cases. All plots were drawn with Prism (Graphpad Software Inc.) or with the Matplotlib (14) or Seaborn Python packages, and data processing used the Pandas package (15). Use of the \pm following mean values indicates the $95 \%$ confidence interval. 


\section{Results}

RA patients express a higher frequency of hypomutated IgG B cell receptors within peripheral blood

200,000 highly purified CD19 ${ }^{\text {+ve }}$ B cells isolated from the peripheral blood of each of 14 newly diagnosed treatment-naïve seropositive early rheumatoid arthritis (ERA) patients (cohort 1/Supplementary Table 1) and 16 healthy controls were sequenced by NGS. The degree of mutation of the IgG heavy chain (IgG-Vh) was calculated by assessing the number of nucleotide mismatches between each sequence read and the closest predicted germline $\mathrm{V}$ segment sequence. Whereas the number of mutations per IgG read approximated to a symmetrical distribution in healthy individuals, the distribution of mutations in RA donors was skewed by the presence of an increased frequency of poorly mutated IgG sequences [Figure 1A-B/ Supplementary figure 2]. This observation was confirmed in a larger cohort of 113 newly diagnosed, DMARD naïve, seropositive ERA patients, selected from the Scottish Early Rheumatoid Arthritis (SERA) inception cohort(16) (cohort 2/Supplementary Table 2). A bimodal distribution of IgG-Vh mutation counts was observed in the lgG-Vh sequences with the first peak representing poorly mutated IgG sequences [Figure $1 \mathrm{C}$ ]. To establish if this population persisted in patients with established RA (ESRA), we sequenced the IgG-Vh sequences from 16 ESRA donors (cohort 3/Supplementary Table 3). Analysis of the mean IgG mutation count per read showed that there were fewer lgG-Vh mutations in both of the ERA and ESRA cohorts, compared to healthy control donors [Figure 1D]. A further 12 paired samples taken 6 months following DMARD therapy (Supplementary Table 2) showed that the mean number of IgG-Vh mutations was only slightly increased [16.3 \pm 2.4 compared with 12.8 \pm 1.9 at diagnosis] ( $p<0.006$, Wilcoxon signed-rank test). The skewed distribution of IgG-Vh mutation counts in ERA donors were the result of an increased frequency of IgG sequences with fewer than 5 mutations. Indeed, the mean percentage of the $\lg G$ repertoire composed of fewer than $5 \mathrm{~V}$-segment mutations (hypomutated $\lg$ sequences $\left[\lg \mathrm{G}^{\text {hypoM}}\right]$ ) in all three $\mathrm{RA}$ cohorts was significantly higher than healthy controls (mean for ERA cohorts 1 and 2 was $11.8 \%$ and $15.9 \%$ respectively, and for ESRA $18.5 \%$ compared to the mean for healthy controls of just $3.4 \%$ ) [Figure $1 \mathrm{E}$ ]. We did not detect a correlation between the frequency of IgG ${ }^{\text {hypoM }}$ and the degree of joint inflammation at the time of RA diagnosis as measured by the disease activity 28 joint score (DAS28) [Supplementary Figure 2B], which makes it unlikely that the presence of $\mathrm{Ig} \mathrm{G}^{\text {hypoM }}$ was simply a result of more marked inflammation.

\section{Hypomutated sequences are distributed throughout the IgG repertoire}

A potential explanation for the increased frequency of $\mathrm{IgG}^{\text {hypoM }}$ in RA donors could be monoor oligo-clonal expansion of IgG B cell clonotypes with few mutations. However, this was 
unlikely given that the $\lg \mathrm{G}^{\text {hypoM }}$ sequences were not restricted to particular IGHV allele families [Figure 2A and supplementary figure 3]. The IGHV4-34 gene segment, that conveys selfreactivity and is strongly associated with a failure of $B$ cell tolerance and autoimmunity(17-19) is censored at multiple check points in healthy individuals(20). Yet, this was significantly higher in the $\operatorname{lgG}^{+v e} B$ cells from 113 DMARD naïve RA patients $(2.41 \%, 95 \%$ C.I. $1.98-2.83 \%)$ compared to healthy controls $0.65 \%$, (95\% C.I. 0.50- 0.79\%) [Figure 2B]. Somatic mutations within the IGHV4-34 gene reduce self-reactivity $(21,22)$ but the IGHV4-34 allele in RA IgG ${ }^{+v e}$ BCRs expressed significantly fewer mutations than the healthy controls $\left(p<7.31 \times 10^{-7}\right)$ [Figure $2 \mathrm{C}$ ]. This demonstrates that RA patients express considerably more BCRs that utilize a poorly mutated IGHV4-34 allele. The IGHV4-34 allele is unusual in that it contains an Ala-Val-Tyr (AVY) motif (within the framework 1 region) responsible for the self-reactivity towards $1 / \mathrm{i}$ carbohydrate antigens $(18,23,24)$. There was no detectable difference in the mutation rate of AVY motifs between RA or healthy control donors in sequences of either the IgG or IgM isotype [Figure 2D]. The Asn-X-Ser N-glycosylation site (NHS) in the CDR2 region is associated with binding to commensal bacteria by innate like $B$ cells $(25)$ and is usually mutated in IgG ${ }^{+v e} B$ cells(22). In RA patients the proportion of IGHV4-34 IgG sequences where the NHS N-glycosylation motif was still intact was significantly higher (46.8\% [IQR:33.6\%$59.9 \%$ ]) compared to healthy control donors (26.9\% [IQR:21.1\%-32.6\%]) [Figure 2E]. Hence RA patients express significantly more polyclonal, hypomutated self-reactive lgG ${ }^{+v e} B C R s$.

\section{IgG ${ }^{\text {hypoM }}$ sequences are not caused by oligoclonal expansions of poorly mutated lgG+ve BCRs}

To confirm the polyclonal nature of the $\lg \mathrm{G}^{\text {hypoM }} \mathrm{BCR}$ sequences, an equality metric called the Gini coefficient was used to compare the degree of clonal expansion in the hypo- and hypermutated compartments of each patient's repertoire. The Gini coefficients of the $\operatorname{lgG}^{\text {hypoM }}$ and hypermutated IgG repertoires of each patient from cohort 2 were similar, indicating that both the hypo- and hyper-mutated components of the repertoire have similar clonotypic frequency structures [Figure 3A]. We further investigated the degree of clonal dominance of IgGypom compared to hypermutated sequences from RA donors at the time of diagnosis and healthy controls derived from cohort 1 where an average of 200,000 BCRs were sequenced per donor. Concurring with two recently published reports on NGS of RA BCRs, the majority of RA patients and healthy controls expressed some clonotype frequencies greater than $0.5 \%$ of the total sequence reads $(26,27)$ [Figure 3B]. Within these repertoires, both hypermutated and lg $\mathrm{G}^{\text {hypoM }}$ sequences exhibited a similar distribution of clonotype frequencies, including a very large number of clonotypes with single reads [Figure $3 \mathrm{C}$ ]. One explanation for the higher frequency of $\mathrm{IgG}^{\text {hypoM }}$ in RA donors could be the failure of enzymes involved in somatic hypermutation (SHM), such as activation-induced cytidine deaminase (AID) or the subsequent 
mismatch repair enzymes. However mutations were preferentially targeted to the same regions of the IgG-Vh segment in RA and control donors, and there were no inter-group differences in the targeting of mutation hotspots [Supplementary Figures 4-5]. Taken together, these results indicate that the increased prevalence of $\operatorname{lgG}^{\text {hypoM }}$ in RA donors did not result from AID or mismatch repair enzyme impairment or to the mono- or oligo-clonal expansions of lgG+ve BCRs with few mutations.

\section{The $B C R^{\text {hypoM }}$ are expressed by IgG+CD27-ve B cells}

The proportion of $\lg \mathrm{G}^{\text {hypoM }}$ was significantly higher in the $\lg \mathrm{G}^{+\mathrm{ve}} \mathrm{CD} 27^{\text {-ve }} \mathrm{B}$-cell population from RA patients than from either the $\operatorname{lgG}{ }^{+v e} C D 27^{\text {tve }} R A$ population or from the same population in the healthy controls [Figure 4A, Mann-Whitney $U, p<0.015]$. The absolute number of circulating peripheral blood double negative $\left(\operatorname{lgM}^{-v e} \operatorname{lgD}{ }^{-v e} C D 27^{-v e}\right) B$ cells in RA patients was also significantly increased at the time of diagnosis and did not change following six months therapy [Figure 4B]. Within individual RA patients, the number of double negative $B$ cells at baseline and following six months of DMARD therapy was still clearly correlated, suggesting that they did not decrease significantly with synthetic DMARD treatment [Figure 4C]. Importantly the increase in double negative $B$ cells was also reflected in a significant increase in the frequency of $\lg \mathrm{G}^{+\mathrm{ve}} \mathrm{CD} 27^{-\mathrm{ve}} \mathrm{B}$ cells [Figure $4 \mathrm{D}$ ]. $\lg \mathrm{G}^{+\mathrm{ve}} \mathrm{CD} 27^{\text {-ve }}$ B-cells from RA patients expressed significantly less CD24, CD21 and CD138 but similar levels of CD38, CD73 and CD1c when compared to the same subset in healthy controls [Figure 4E].

\section{$\operatorname{lgG}^{+v e} \mathrm{CD} 27^{-\mathrm{ve}} \mathrm{B}$ cells are enriched in the synovium and secrete pro-inflammatory cytokines}

Utilising paired blood and synovial tissue from ESRA patients undergoing joint arthroplasty (cohort 4/ Supplementary table 4), revealed that the synovium was enriched for both $\operatorname{lgG}^{+v e} B$ cells [Figure $5 \mathrm{~A}$ ] and $\lg \mathrm{G}^{+\mathrm{ve}} \mathrm{CD} 27^{-\mathrm{ve}} \mathrm{B}$ cells [Figure $5 \mathrm{~B}$ ]. Compared to circulating $\operatorname{lgG}^{+\mathrm{ve}} \mathrm{CD}^{-7^{-}}$ ve $B$ cells, the expression of FCRL4, RANKL, CD73 and CD138 was upregulated, whilst HLADR, CD21, CD40 and CD38 were expressed on fewer synovial $\lg \mathrm{G}^{\text {+ve }} \mathrm{CD} 27^{\text {-ve }} \mathrm{B}$ cells [Figure 5C]. Synovial lgG ${ }^{+v e} \mathrm{CD} 27^{-v e} \mathrm{~B}$-cells expressed significantly more TNF-alpha but similar amounts of $\mathrm{GM}-\mathrm{CSF}$ than either $\operatorname{lgG} \mathrm{ge}^{-\mathrm{C}} \mathrm{CD} 27^{-\mathrm{ve}}$ naïve or $\operatorname{lgG} \mathrm{G}^{+\mathrm{ve}} \mathrm{CD} 27^{\text {tve }}$ memory $\mathrm{B}$ cells of patients with established RA [Figure 5D].

\section{Peripheral blood and synovial B cell repertoires are distinct in RA}

As well as secreting cytokines, synovial B cells are reported to secrete autoantibodies that have undergone SHM within GC like structures(26, 28-30). Paired peripheral and synovial IgG-Vh sequences from RA patients undergoing arthroplasty were sequenced [Figure 6A]. To 
avoid any potential confounding that may occur with increased levels of mRNA in plasma cells, purified $C D 20^{\text {tve }} \mathrm{B}$ cells were analysed. In six out of eight patients the lower quartile of the distribution of somatic mutations was higher in the periphery than in the synovium. The mean number of mutations displayed by the peripheral B cell repertoire of patients (mean $15.27 \pm$ 5.09) was lower than the mean number of mutations displayed by the paired synovial repertoires (mean $19.65 \pm 2.96$, paired t-test, $p=0.02$ ). The RA synovium has been reported to harbour clonal expansions of $B$ cells $(26,30)$. The percentage of the repertoire composed of each unique CDR3 clonotype, was plotted, dividing the BCR sequences into those with greater or fewer than five mutations relative to the predicted germ line sequence [Figure 6B]. No clear preference was noted within either the hypermutated or $\lg \mathrm{G}^{\text {hypoM }}$ sequences in terms of CDR3 clonal frequencies with all four populations expressing CDR3 clonal frequencies greater than $0.5 \%$ of the $\operatorname{lgG}^{+v e} \mathrm{~B}$ cell repertoire.

Finally it was important to determine if RA patients shared BCR sequences that may point to particular pathogenic clonal expansions. The term 'public sequence' is used to describe similar or identical T cell receptor (TCR) or BCR sequences which may arise in different individuals, indicative of a convergent immune response in different individuals to a common antigenic stimulus(31). This may have particular relevance for autoimmune mediated tissue damage including RA. We hypothesised that identical CDR3 sequences would be found in more than one patient either in newly diagnosed DMARD naïve RA patients (cohort 1 ) or within the paired blood and synovial samples of the ESRA patients (cohort 4). We also compared these CDR3 sequences to healthy subjects from the cohort 1 study. Notably, no common CDR3 sequences were found to be shared by the peripheral lgG sequences of the healthy subjects and only 21 CDR3 sequences were shared (ie present in at least 2 individuals) by the peripheral $B$ cell repertoires of RA patients, comprising a tiny fraction of the total repertoire. In addition very few CDR3 sequences were present in both the blood and synovium of the same patient [Figure $6 \mathrm{C}$ ]. Where overlap was seen (in the repertoires of 5 RA patients), it made up less than $0.1 \%$ of the synovial repertoire. To confirm this clonal lineage analysis of all shared sequences was employed to detect any evidence of egression events from the synovial compartment. Only two lineage trees, from patient $\mathrm{B}$ and patient $\mathrm{K}$, showed evidence of egression events from the synovium to the periphery [Figure 6D]. This shows that shared CDR3 sequences were not abundant in the peripheral B cell repertoires of RA patients and that synovial and peripheral blood repertoires are largely independent. In addition, given the extremely low support for egression events from the synovium, there is no evidence to support the hypothesis that the lg $\mathrm{G}^{\text {hypoM }}$ sequences in the peripheral blood $B$ cell repertoires arise in the inflamed synovial joint. 


\section{Discussion}

This is the largest study to date, utilising NGS, to examine the IgG-Vh repertoires of over 150 RA patients. RA patients express significantly more hypomutated $B$ cell receptors within $\lg \mathrm{G}^{+\mathrm{ve}} \mathrm{CD} 27^{-\mathrm{ve}} \mathrm{CD} 24^{\mathrm{lo}} \mathrm{CD} 21^{\text {lo }}$. In patients with established $\mathrm{RA}, \lg \mathrm{G}^{+\mathrm{ve}} \mathrm{CD} 27^{-\mathrm{ve}} \mathrm{CD} 24^{\mathrm{lo}} \mathrm{CD} 21^{\mathrm{lo}} \mathrm{B}$ cells are enriched in the synovium, where they upregulate the expression of FcRL4, RANKL, CD73, CD138 and secrete TNF. Significantly more IgG-Vh utilise the auto reactive allele IGHV4-34, which are again distinctively less mutated than the same allele expressed by healthy controls. Surprisingly there is virtually no sharing of the repertoire between the blood and synovium or between RA patients. The accumulation of $\mathrm{lg} \mathrm{G}^{\text {hypoM }}$ expressing CD27${ }^{\text {ve }} \mathrm{CD} 24^{\text {lo }} \mathrm{CD} 21^{\text {lo }} \mathrm{B}$ cells may both augment the formation of self-reactive immune complexes and pro-inflammatory cytokines. We hypothesise that following B cell depletion therapy, the frequency of $\mathrm{lg} \mathrm{G}^{\text {hypoM }}$ would gradually increase to a critical threshold prior to a flare of synovitis.

A previous report alludes to the loss of clonally expanded populations of B cells from the peripheral blood into the synovium at the time of RA onset (27). Assessing a greater number of IgG sequences we observed expanded populations of $B$ cells in both RA and healthy controls, making it difficult to see how dominant BCR clones could predict the onset of RA in at-risk individuals. Despite RA being a heterogenous disease, we expected to find particular IgGVh-CDR3 clones that were shared in the blood or synovium of RA patients. Instead the repertoire overlap analysis demonstrated a very low number of multi-compartmental IgG sequences when compared to the overall size of either repertoire, suggesting that the peripheral and synovial B cell repertoires are quite distinct within and between patients. The cause for this may, as previously reported, arise from the migration of peripheral blood B cells into the synovium(27). As synovial B cells express distinct chemokine receptors from peripheral $B$ cells, they may be sequestered within the synovium and rarely be observed in the peripheral blood again(32). In line with this, we observed only two B cell clones that showed evidence of a migration event from the synovium into the peripheral blood. We also noted a scarcity of public CDR3 sequences in the peripheral $B$ cell repertoire between RA patients, which was surprising if RA is an antigen-driven disease. Given that different immunoglobulins with similar (but not identical) physiochemical properties can recognise the same antigen epitope(33), it is still possible that lgG sequences that react to the same epitope are not identical.

The stimuli driving the emergence of such a high frequency of class switched $\lg G^{\text {hypoM }}$, that approached $40 \%$ of the IgG-Vh repertoire in some RA patients, is currently unknown. Central and peripheral tolerance checkpoints are known to be defective in RA patients, leading to the accumulation of naïve autoreactive B cells in the periphery(34). Activation of naïve B cells, 
facilitated by $T$ cell help and/or TLR ligands, induces class switching outwith the germinal centre(35). The high frequency of IgGypoM in RA patients stongly suggests that they have arisen from an ongoing extrafollicular response. Given the lack of NHS N-glycosylation motif mutations within the self-reactive IGHV4-34 IgG sequences, we hypothesise that these Ig $\mathrm{G}^{\text {hypoM }} \mathrm{B}$ cells arise from an expanded pool of self-reactive innate like $B$ cells(25). CD27${ }^{v e} \mathrm{IgD}^{\text {-ve }} \mathrm{B}$ cells are increased in the blood of RA patients both at diagnosis and following synthetic DMARD therapy(36-38). CD27 is widely used as a marker of human memory B cells, but $\mathrm{CD} 27^{-\mathrm{ve}} \mathrm{IgG} \mathrm{g}^{+\mathrm{ve}} \mathrm{B}$ cells also contain a pool of short-lived memory cells $(8,39,40)$. They are substantially increased in the blood of patients with SLE, correlate with a higher disease activity index(41) and are significantly diminished in SLE patients following rituximab therapy(42). Over time an increasing number of RA patients are failing to respond to multiple synthetic and biologic DMARD therapies. Future work will explore if these refractory RA patients express more $\lg \mathrm{G}^{\text {hypoM }} \mathrm{CD} 27^{-\mathrm{ve}} \mathrm{IgG}{ }^{\text {+ve }} \mathrm{B}$ cells and if their emergence following BCDT foretells clinical disease relapse.

\section{Author contributions}

GC, KM and CG carried out experiments. GC, LC, SG undertook the bioinformatics analysis. $\mathrm{HJ}$ and SB contributed to clinical data and/or sample collection. MG, GC and DG designed the experiments, analyzed the data, and wrote the manuscript. IMcl and $\mathrm{HJ}$ reviewed the manuscript and IMcl managed the SERA inception cohort.

Acknowledgements This work has made use of the resources provided by the Edinburgh Compute and Data Facility (ECDF) (http://www.ecdf.ed.ac.uk/). The authors thank the staff from the QMRI Flow Cytometry Facility for help with cell sorting. 


\section{Figure Legends}

\section{Figure 1 Legend}

A. Distribution of the number of IgG-Vh mismatches per sequencing read for DMARD naïve early RA patients (ERA) $(n=14)$ and healthy control donors $(n=16)$. Individual density plots are stacked to indicate the overall distribution across all samples in each group. Maximum cumulative density values for each group are normalised to the mode to facilitate inter-group comparison.

B. Skewness of IgG mutation distributions from RA patients $(n=14)$ and healthy control groups $(n=16)$. Horizontal lines denote the arithmetic mean skewness for each group. $P$ value shown was calculated using Mann-Whitney $U$ test.

C. Distribution of the number of $V$ segment mismatches per sequencing read for $E R A$ patients [cohort 2, $n=113$ ]. Individual density plots are stacked to indicate the overall distribution across all samples in each group.

D. Mean IgG-Vh mismatches for control donors $(n=16)$, ERA donors from cohorts 1 and $2(n=14$ and $n=113$ respectively) and ESRA from cohort $3(n=16)$. P values are generated by Kruskal-Wallis test with Dunn's post-test to compare the means for each RA group with the control donor group.

E. Percentage of IgG reads with fewer than 5 mutations for healthy donors from cohort $1(n=16)$, ERA donors from cohort 1 and cohort $2(n=14$ and $n=113)$ and ESRA donors from cohort $3(n=16)$.

\section{Figure 2 Legend}

A. The mean number of IgG-Vh $\vee$ segment mismatches per read for each individual in the ERA $(n=113)$ and healthy control groups $(n=16)$. Data are split by germline IGHV family group. White circles denote group means, vertical white lines show the $95 \%$ confidence interval for the mean.

B. Percentage of IgG reads that use the IGHV4-34 allele in ERA patients (Cohort 2, $n=113$ ) and control donors (cohort $1, n=16$ ). $P$ value calculated using Kruskal Wallis with Dunn's post-hoc pairwise test, and with Holm-Šídák correction for multiple comparisons of group means.

C. Mean number of IgG-Vh mismatches per read for ERA donors $(n=113$, cohort 2$)$ and heathy control donors $(n=16)$. For each donor, the mean number of mutations for all reads mapping to IGHV4-34, or to other IGHV alleles, were calculated and plotted independently.

D. Proportion of IGHV4-34 reads of IgG and IgM Isotypes where the carbohydrate binding AVY motif within framework region 1 (IMGT numbering 24-26) has an unchanged amino acid sequence. 
E. Proportion of IGHV4-34 IgG sequences where the NHS glycosylation motif within CDR2 (amino acid residues 57-59, IMGT numbering scheme) has an unchanged amino acid sequence. $P$ value calculated using t-test (2 tailed) to compare the group means.

\section{Figure 3 Legend}

A. Gini coefficients of IgG sequences for each RA donor from cohort 2 ( $n=113)$. Gini coefficients are a measure of inequality of distribution, where a value of 0 indicates perfect equality (all IgG clonotypes of equal proportion). The Gini coefficient was calculated independently for hypomutated (Fewer than 5 mismatches) or hypermutated (5 or more mismatches) sequences to compare the degree of clonal expansion in each category.

B. Percentage of the IgG-Vh repertoire composed of unique CDR3 clonotypes from ERA patients (cohort $1, n=14$ ), with sequences split into hypermutated (5 mismatches or more) and hypomutated (fewer than 5 mismatches).

C. As for $3 B$ from the three individual $R A$ donors with the greatest frequency of hypomutated B-cells (in cohort 1 ).

\section{Figure 4 Legend}

A. Prevalence of hypomutated $V$ segment sequences in $C D 27^{\text {ve }}$ and $C D 27^{\text {-ve }} \operatorname{lgG}{ }^{\text {tve }} B$ cells from RA and control donors. White spots indicate individual data points for each donor ( $n=4$ per group)

B. Whole blood was stained for flow cytometry to determine cell number. $\operatorname{lgD}^{-\mathrm{ve}} \operatorname{lgM}^{-}$ ${ }^{v e} \mathrm{CD} 27^{-\mathrm{ve}} \mathrm{B}$ cells were gated and cells $/ \mathrm{ml}$ calculated. $\mathrm{N}=35 \mathrm{HD}, 40 \mathrm{RA}(0 \mathrm{~m}), 39$ $\mathrm{RA}(6 \mathrm{~m})$.

C. Paired baseline and 6 month data from Fig 4B was used to determine if the frequency of $\lg \mathrm{D}^{-\mathrm{ve}} \operatorname{lgM}^{-\mathrm{ve}} \mathrm{CD} 27^{-\mathrm{ve}} \mathrm{B}$ cells was correlated in the same patient 6 months following DMARD therapy.

D. PBMCs from control donors and RA patients were stained for flow cytometry. Cells were gated for $\mathrm{CD} 20^{+v e} \mathrm{CD} 19^{+v e} / g G^{+v e} \mathrm{~B}$ cells then the proportion of $\mathrm{CD} 27^{\text {-ve }}$ cells determined. $\mathrm{N}=22 \mathrm{HD}, 40 \mathrm{RA}$.

E. Cell surface markers of $\operatorname{lgG}{ }^{+v e} \mathrm{CD} 27^{-\mathrm{ve}} \mathrm{B}$ cell population were analysed by flow cytometry. Cells were gated as Fig 4D. N=13 HD \& 16 RA

\section{Figure 5 Legend}


A. Flow cytometry of paired peripheral blood (PB) and synovial tissue B cells from RA patients taken at the time of undergoing arthroplasty. The graph shows the percentage of $\operatorname{lgG}^{+v e} B$ cells within the $C D 20^{+v e} \mathrm{CD} 19^{\text {vve }} B$ cell population. $\mathrm{N}=24$

B. $C D 20^{\text {tve }} C D 19^{\text {tve }}$ population as for $(A)$. Graph shows the percentage of $\lg G^{\text {tve }} \mathrm{CD} 7^{\text {-ve }}$ $B$ cells within this $B$ cell population. $N=24$

C. Plots show the percentage of cells positive for the surface markers of paired PB and synovial samples within the $\operatorname{lgG}^{\text {tve }} \mathrm{CD} 27^{-\mathrm{ve}} \mathrm{B}$ cell subset. $\mathrm{N}=8$

D. Representative flow cytometry plots showing the intracellular cytokine staining of stimulated $\operatorname{lgG}{ }^{\text {+ve }} \mathrm{CD} 27^{\text {-ve }}$ and $\lg \mathrm{G}^{+\mathrm{ve}} \mathrm{CD} 27^{\text {tve }} \mathrm{B}$ cell subsets for TNF-alpha and GMCSF (i). Pooled data for (ii) TNF-alpha and (iii) GM-CSF. Each point represents an individual patient sample. $\mathrm{N}=11$

\section{Figure 6 Legend}

A. Distributions of mutation counts from paired peripheral blood (blue) and synovial (red) $\lg$ sequence repertoires from each of 8 RA patients with ESRA undergoing arthroplasty. The central horizontal line indicates the median of each distribution, with the upper and lower dashed lines representing the upper and lower quartiles respectively.

B. Percentage of the repertoire composed of each CDR3 clonotype for paired synovial $(\mathrm{S})$ and peripheral blood $(\mathrm{P})$ samples from each of the $8 \mathrm{RA}$ patients shown in 6A (cohort 4).

C. Repertoire overlap of synovial (red) and peripheral blood (blue) lgG repertoires of the RA patients. Each Venn diagram represents a single patient. The number of unique, non-singeton IgG sequences in the repertoire from each compartment is depicted at the centre of each circle, and shared sequences are enumerated at the intersection between the two circles. Two shared sequences are considered identical if they possessed the same CDR3 nucleotide sequence and used the same $\mathrm{V}$ and $\mathrm{J}$ gene segments.

D. Lineage trees of $B$ cell clones that show evidence of egression from the synovium into the periphery of RA patients, inferred for i) clone 36 from patient B and ii) clone 282 from patient $\mathrm{K}$. Each node represents a unique non-singleton IgG sequence with the size of the node scales non-linearly in proportion to the number of sequence duplicated observed. The label at the centre of each node represents the tissue origin of the sequence, and node colour indicates the number of somatic mutations present in the clone sequence. Red arrows mark egression events from the synovium to the periphery. Lineage trees were inferred using PHYLIP v3.6 and plotted in Gephi v0.92. 


\section{References}

1. Mclnnes IB, Schett $\mathrm{G}$. The pathogenesis of rheumatoid arthritis. N Engl J Med. 2011;365(23):2205-19.

2. Edwards JC, Szczepanski L, Szechinski J, Filipowicz-Sosnowska A, Emery P, Close $\mathrm{DR}$, et al. Efficacy of B-cell-targeted therapy with rituximab in patients with rheumatoid arthritis. N Engl J Med. 2004;350(25):2572-81.

3. Keystone E, Emery P, Peterfy CG, Tak PP, Cohen S, Genovese MC, et al. Rituximab inhibits structural joint damage in patients with rheumatoid arthritis with an inadequate response to tumour necrosis factor inhibitor therapies. Annals of the Rheumatic Diseases. 2009;68(2):216-21.

4. Porter D, van Melckebeke J, Dale J, Messow CM, McConnachie A, Walker A, et al. Tumour necrosis factor inhibition versus rituximab for patients with rheumatoid arthritis who require biological treatment (ORBIT): an open-label, randomised controlled, non-inferiority, trial. Lancet. 2016;388(10041):239-47.

5. Nielen MM, van Schaardenburg D, Reesink HW, van de Stadt RJ, van der HorstBruinsma IE, de Koning MH, et al. Specific autoantibodies precede the symptoms of rheumatoid arthritis: a study of serial measurements in blood donors. Arthritis Rheum. 2004;50(2):380-6.

6. Cambridge G, Perry HC, Nogueira L, Serre G, Parsons HM, De La Torre I, et al. The effect of B-cell depletion therapy on serological evidence of B-cell and plasmablast activation in patients with rheumatoid arthritis over multiple cycles of rituximab treatment. $\mathrm{J}$ Autoimmun. 2014;50:67-76.

7. Quartuccio L, Salvin S, Saracco M, Lombardi S, Fabris M, Mansutti E, et al. [Rheumatoid factor positivity rather than anti-CCP positivity, a lower disability and a lower number of anti-TNFalpha agents failed are associated with response to rituximab in rheumatoid arthritis]. Reumatismo. 2009;61(3):182-6.

8. Dorner T, Radbruch A. Selecting B cells and plasma cells to memory. J Exp Med. 2005;201(4):497-9.

9. Bashford-Rogers RJM, Smith KGC, Thomas DC. Antibody repertoire analysis in polygenic autoimmune diseases. Immunology. 2018;155(1):3-17.

10. Dale J, Paterson C, Tierney A, Ralston SH, Reid DM, Basu N, et al. The Scottish Early Rheumatoid Arthritis (SERA) Study: an inception cohort and biobank. BMC Musculoskelet Disord. 2016;17(1):461.

11. Oliphant TE. Python for scientific computing. Computing in Science \& Engineering. 2007;9(3):10-20.

12. Terpilowski MA. scikit-posthocs: Pairwise multiple comparison tests in Python. Journal of Open Source Software. 2019;4(1169).

13. Holm S. A simple sequentially rejective multiple test procedure. Scandinavian Journal of Statistics. 1979;6:65-70.

14. Hunter JD. Matplotlib: A 2D Graphics Environment. Computing in Science \& Engineering. 2007;9(3):90-5.

15. McKinney W, editor Data Structures for Statistical Computing in Python. The 9th Python in Science Conference 2010.

16. Dale J, Paterson C, Tierney A, Ralston SH, Reid DM, Basu N, et al. The Scottish Early Rheumatoid Arthritis (SERA) Study: an inception cohort and biobank. BMC Musculoskeletal Disorders. 2016:1-8.

17. Cappione A, 3rd, Anolik JH, Pugh-Bernard A, Barnard J, Dutcher P, Silverman G, et al. Germinal center exclusion of autoreactive B cells is defective in human systemic lupus erythematosus. J Clin Invest. 2005;115(11):3205-16.

18. Richardson C, Chida AS, Adlowitz D, Silver L, Fox E, Jenks SA, et al. Molecular basis of $9 \mathrm{G} 4 \mathrm{~B}$ cell autoreactivity in human systemic lupus erythematosus. J Immunol. 2013;191(10):4926-39. 
19. Zheng NY, Wilson K, Wang X, Boston A, Kolar G, Jackson SM, et al. Human immunoglobulin selection associated with class switch and possible tolerogenic origins for $\mathrm{C}$ delta class-switched B cells. J Clin Invest. 2004;113(8):1188-201.

20. Pugh-Bernard AE, Silverman GJ, Cappione AJ, Villano ME, Ryan DH, Insel RA, et al. Regulation of inherently autoreactive $\mathrm{VH} 4-34 \mathrm{~B}$ cells in the maintenance of human $\mathrm{B}$ cell tolerance. J Clin Invest. 2001;108(7):1061-70.

21. Reed JH, Jackson J, Christ D, Goodnow CC. Clonal redemption of autoantibodies by somatic hypermutation away from self-reactivity during human immunization. J Exp Med. 2016;213(7):1255-65.

22. Sabouri Z, Schofield P, Horikawa K, Spierings E, Kipling D, Randall KL, et al. Redemption of autoantibodies on anergic $B$ cells by variable-region glycosylation and mutation away from self-reactivity. Proc Natl Acad Sci U S A. 2014;111(25):E2567-75. 23. Potter KN, Hobby P, Klijn S, Stevenson FK, Sutton BJ. Evidence for involvement of a hydrophobic patch in framework region 1 of human V4-34-encoded Igs in recognition of the red blood cell I antigen. J Immunol. 2002;169(7):3777-82.

24. Thorpe SJ, Ball C, Fox B, Thompson KM, Thorpe R, Bristow A. Anti-D and anti-i activities are inseparable in V4-34-encoded monoclonal anti-D: the same framework 1 residues are required for both reactivities. Transfusion. 2008;48(5):930-40.

25. Schickel JN, Glauzy S, Ng YS, Chamberlain N, Massad C, Isnardi I, et al. Selfreactive VH4-34-expressing IgG B cells recognize commensal bacteria. J Exp Med. 2017;214(7):1991-2003.

26. Doorenspleet ME, Klarenbeek PL, de Hair MJH, van Schaik BDC, Esveldt REE, van Kampen AHC, et al. Rheumatoid arthritis synovial tissue harbours dominant B-cell and plasma-cell clones associated with autoreactivity. Annals of the Rheumatic Diseases. 2014;73(4):756-62.

27. Tak PP, Doorenspleet ME, de Hair MJH, Klarenbeek PL, van Beers-Tas MH, van Kampen AHC, et al. Dominant B cell receptor clones in peripheral blood predict onset of arthritis in individuals at risk for rheumatoid arthritis. Annals of the Rheumatic Diseases. 2017;76(11):1924-30.

28. Rochas C, Hillion S, Youinou P, Jamin C, Devauchelle-Pensec V. RAG-mediated secondary rearrangements of B-cell antigen receptors in rheumatoid synovial tissue. Autoimmunity reviews. 2007;7(2):155-9.

29. Randen I, Mellbye OJ, Førre O, Natvig JB. The identification of germinal centres and follicular dendritic cell networks in rheumatoid synovial tissue. Scandinavian journal of immunology. 1995;41(5):481-6.

30. Itoh K, Patki V, Furie RA, Chartash EK, Jain RI, Lane L, et al. Clonal expansion is a characteristic feature of the B-cell repetoire of patients with rheumatoid arthritis. Arthritis Res. 2000;2(1):50-8.

31. Pogorelyy MV, Minervina AA, Chudakov DM, Mamedov IZ, Lebedev YB, Mora T, et al. Method for identification of condition-associated public antigen receptor sequences. Elife. 2018;7.

32. Henneken M, Dorner T, Burmester GR, Berek C. Differential expression of chemokine receptors on peripheral blood $B$ cells from patients with rheumatoid arthritis and systemic lupus erythematosus. Arthritis Res Ther. 2005;7(5):R1001-13.

33. Nair DT, Singh K, Siddiqui Z, Nayak BP, Rao KV, Salunke DM. Epitope recognition by diverse antibodies suggests conformational convergence in an antibody response. $\mathrm{J}$ Immunol. 2002;168(5):2371-82.

34. Samuels J, Ng YS, Coupillaud C, Paget D, Meffre E. Impaired early B cell tolerance in patients with rheumatoid arthritis. J Exp Med. 2005;201(10):1659-67.

35. Roco JA, Mesin L, Binder SC, Nefzger C, Gonzalez-Figueroa P, Canete PF, et al. Class-Switch Recombination Occurs Infrequently in Germinal Centers. Immunity. 2019;51(2):337-50 e7.

36. Nakayamada S, Kubo S, Yoshikawa M, Miyazaki Y, Yunoue N, Iwata S, et al. Differential effects of biological DMARDs on peripheral immune cell phenotypes in patients with rheumatoid arthritis. Rheumatology (Oxford). 2018;57(1):164-74. 
37. Moura RA, Quaresma C, Vieira AR, Goncalves MJ, Polido-Pereira J, Romao VC, et al. B-cell phenotype and IgD-CD27- memory B cells are affected by TNF-inhibitors and tocilizumab treatment in rheumatoid arthritis. PLoS One. 2017;12(9):e0182927.

38. Mahmood Z, Muhammad K, Schmalzing M, Roll P, Dorner T, Tony HP. CD27-IgDmemory $B$ cells are modulated by in vivo interleukin-6 receptor (IL-6R) blockade in rheumatoid arthritis. Arthritis Res Ther. 2015;17:61.

39. Fecteau JF, Cote G, Neron S. A new memory CD27-IgG+ B cell population in peripheral blood expressing $\mathrm{VH}$ genes with low frequency of somatic mutation. J Immunol. 2006;177(6):3728-36.

40. Wirths $S$, Lanzavecchia $A$. ABCB1 transporter discriminates human resting naive $B$ cells from cycling transitional and memory B cells. Eur J Immunol. 2005;35(12):3433-41. 41. Wei C, Anolik J, Cappione A, Zheng B, Pugh-Bernard A, Brooks J, et al. A New Population of Cells Lacking Expression of CD27 Represents a Notable Component of the B Cell Memory Compartment in Systemic Lupus Erythematosus. Journal of Immunology. 2007;178(10):6624-33.

42. Anolik JH, Barnard J, Cappione A, Pugh-Bernard AE, Felgar RE, Looney RJ, et al. Rituximab improves peripheral $B$ cell abnormalities in human systemic lupus erythematosus. Arthritis Rheum. 2004;50(11):3580-90.

43. Picelli S, Faridani OR, Bjorklund AK, Winberg G, Sagasser S, Sandberg R. Fulllength RNA-seq from single cells using Smart-seq2. Nat Protoc. 2014;9(1):171-81.

44. FLASH: fast length adjustment of short reads to improve genome assemblies., (2011).

45. Glanville J, Zhai W, Berka J, Telman D, Huerta G, Mehta GR, et al. Precise determination of the diversity of a combinatorial antibody library gives insight into the human immunoglobulin repertoire. Proc Natl Acad Sci U S A. 2009;106(48):20216-21.

46. Gupta NT, Vander Heiden JA, Uduman M, Gadala-Maria D, Yaari G, Kleinstein SH. Change-O: a toolkit for analyzing large-scale $B$ cell immunoglobulin repertoire sequencing data. Bioinformatics. 2015;31(20):3356-8.

47. Vander Heiden JA, Yaari G, Uduman M, Stern JN, O'Connor KC, Hafler DA, et al. pRESTO: a toolkit for processing high-throughput sequencing raw reads of lymphocyte receptor repertoires. Bioinformatics. 2014;30(13):1930-2.

48. Wickham H. ggplot2 : elegant graphics for data analysis. New York ; London: Springer; 2009.

49. Wickham H. The Split-Apply-Combine Strategy for Data Analysis. 2011. 2011;40(1):29.

50. R Development Core Team. R: A Language and Environment for Statistical Computing. Vienna, Austria: R Foundation for Statistical Computing; 2018. 
Figure 1 bioRxiv preprint doi: https://doi.org/10.1101/771949; this version posted September 18, 2019. The copyright holder for this preprint (which
was not certified by peer review) is the author/funder. All rights reserved. No reuse allowed without permission.

Figure 1 bioRxiv preprint doi: https://doi.org/10.1101/771949; this version posted September 18,2019 . The copyright holder for this preprint (which
was not certified by peer review) is the author/funder. All rights reserved. No reuse allowed without permission.
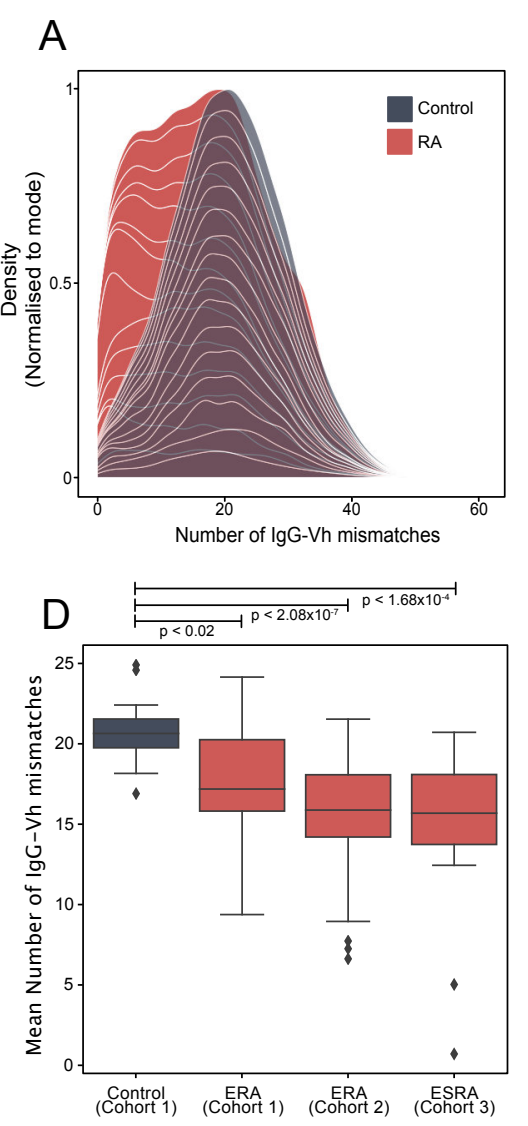

B
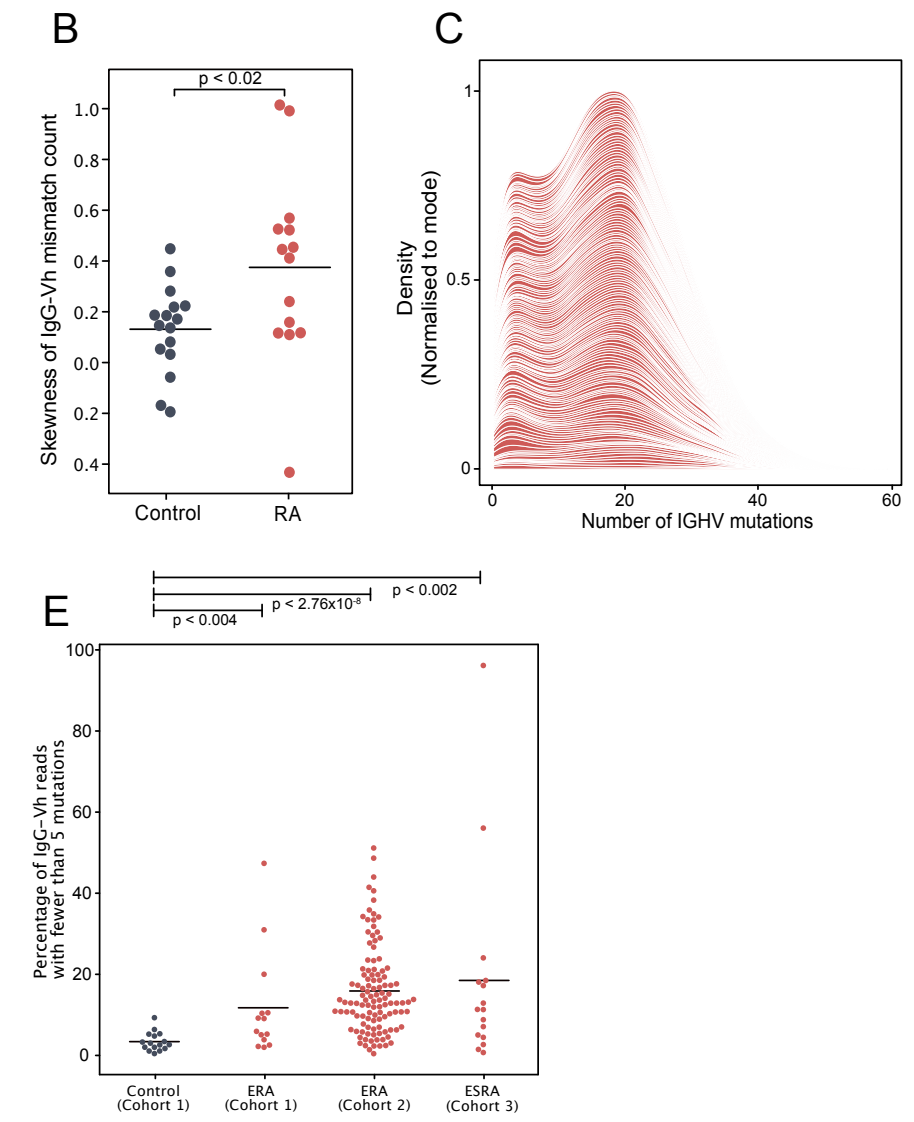
Figure 3bioRxiv preprint doi: https://doi.org/10.1101/771949; this version posted September 18, 2019. The copyright holder for this preprint (which was not certified by peer review) is the author/funder. All rights reserved. No reuse allowed without permission.

\section{A}

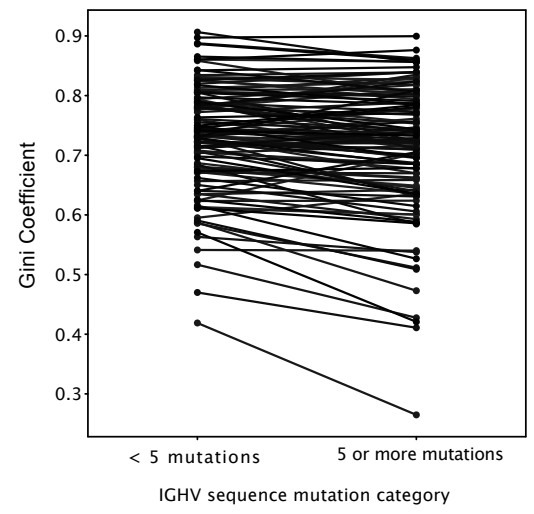

C

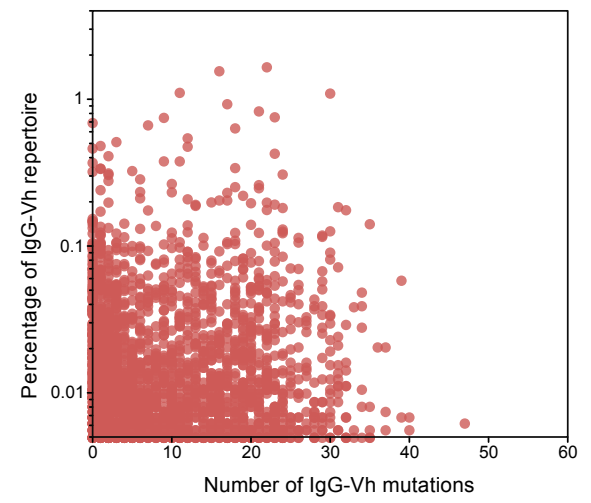

B

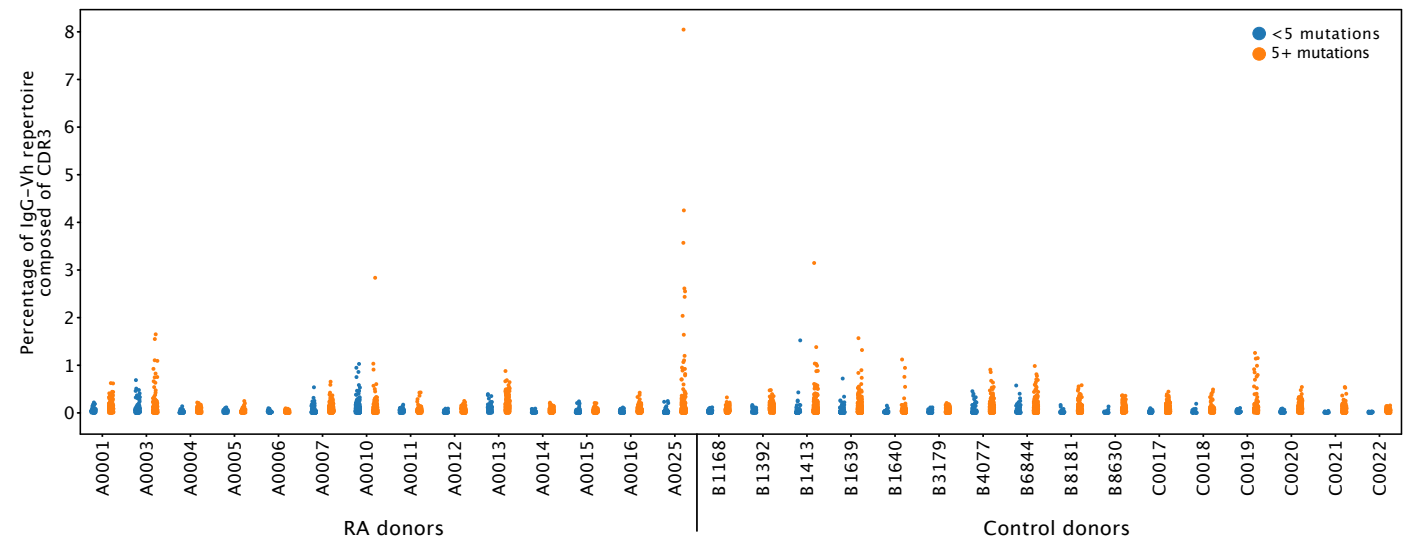

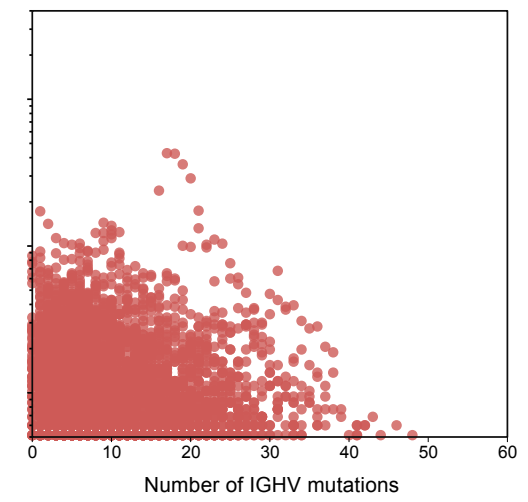




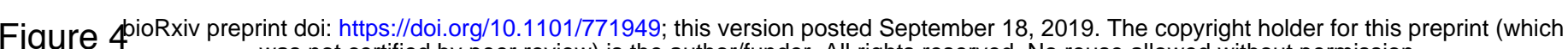
was not certified by peer review) is the author/funder. All rights reserved. No reuse allowed without permission.

A

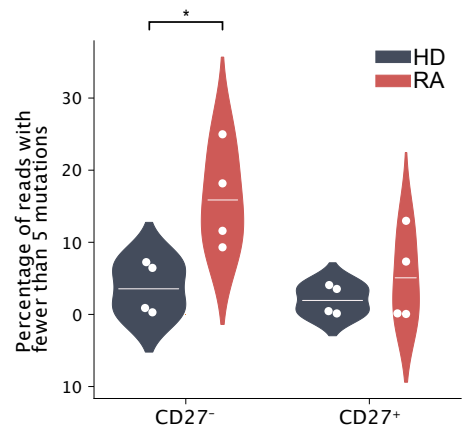

B

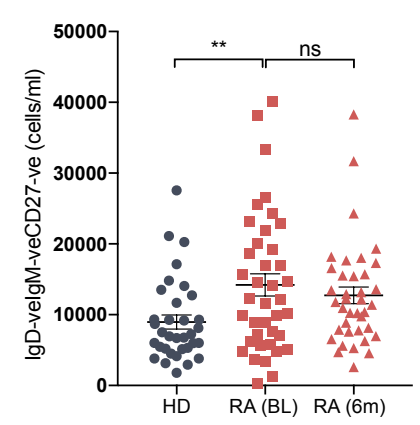

C

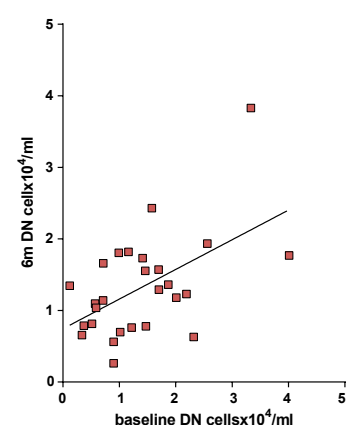

D

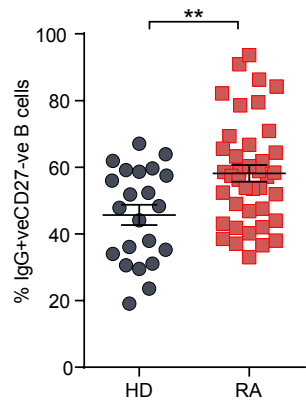

E

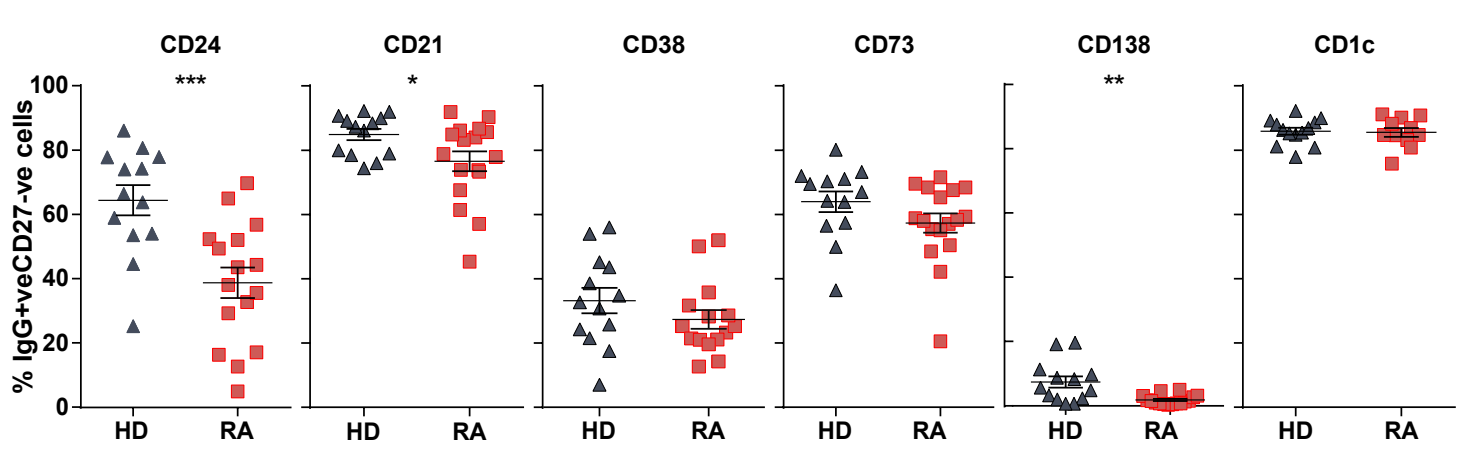


Figure 5bioRxiv preprint doi: https://doi.org/10.1101/771949; this version posted September 18, 2019. The copyright holder for this preprint (which was not certified by peer review) is the author/funder. All rights reserved. No reuse allowed without permission.

A
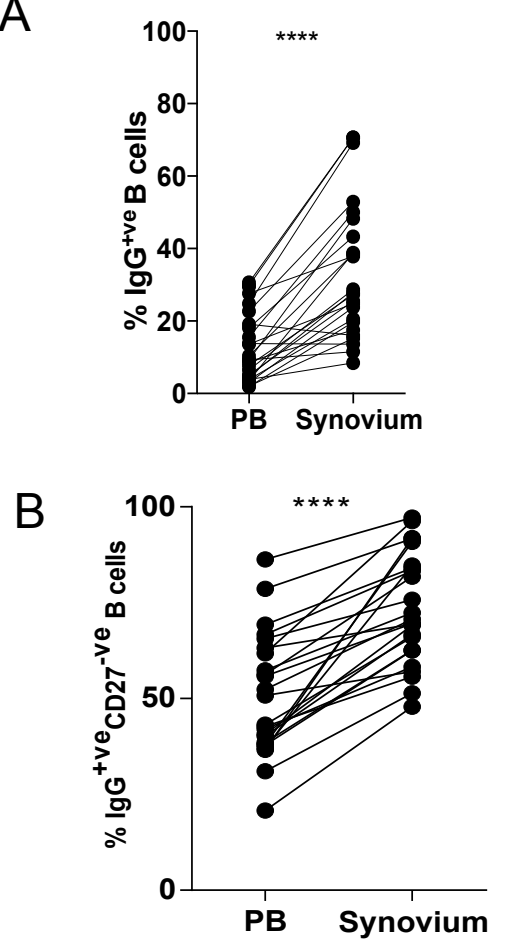

C

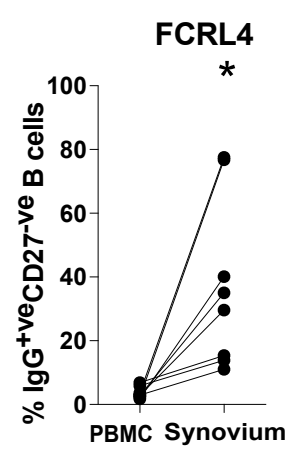

RANKL

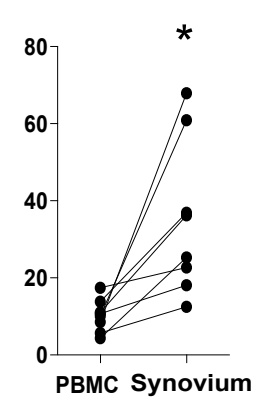

CD21

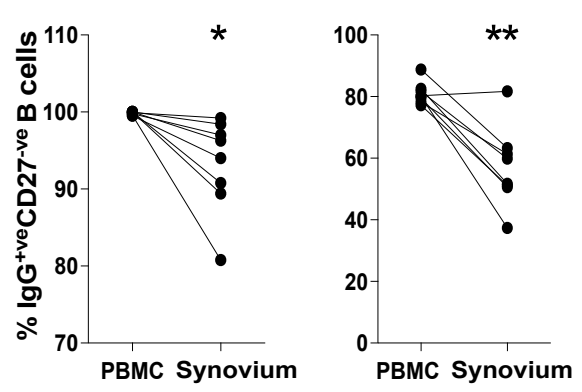

PBMC Synovium

ii

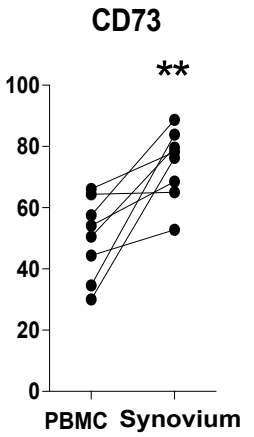

CD40

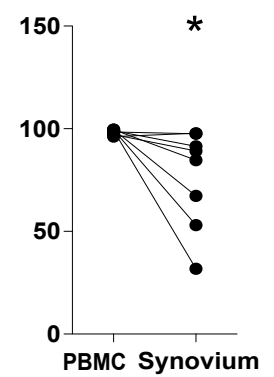

CD138

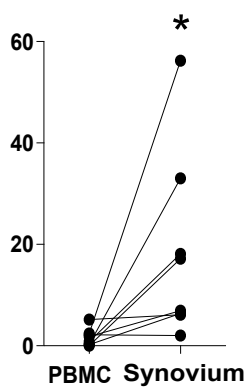

CD38

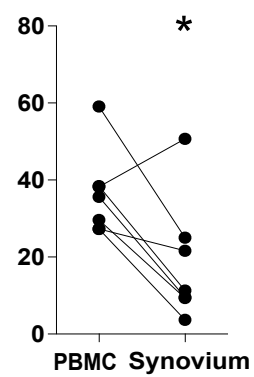

D

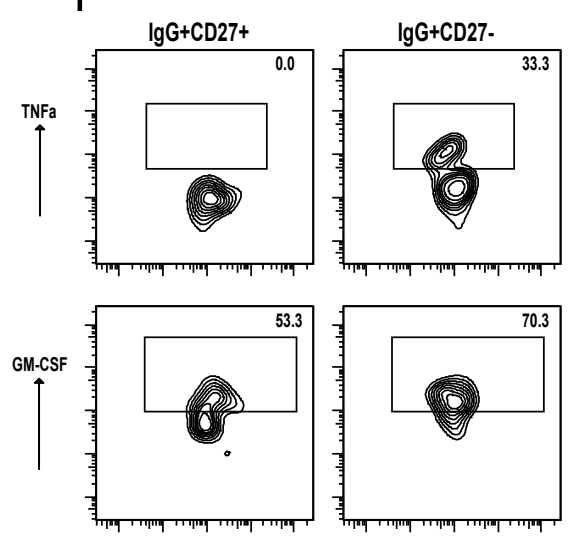

TNF-alpha

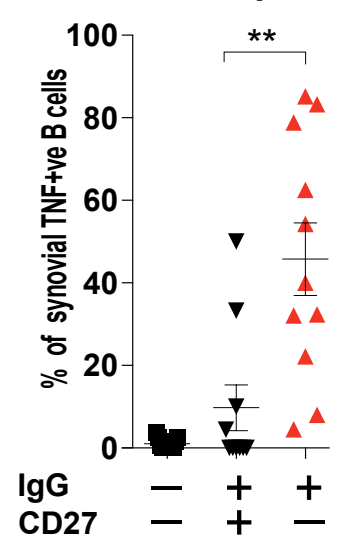

iii 
Figure 6 bioRxiv preprint doi: https://doi.org/10.1101/771949; this version posted September 18, 2019. The copyright holder for this preprint (which was not certified by peer review) is the author/funder. All rights reserved. No reuse allowed without permission.
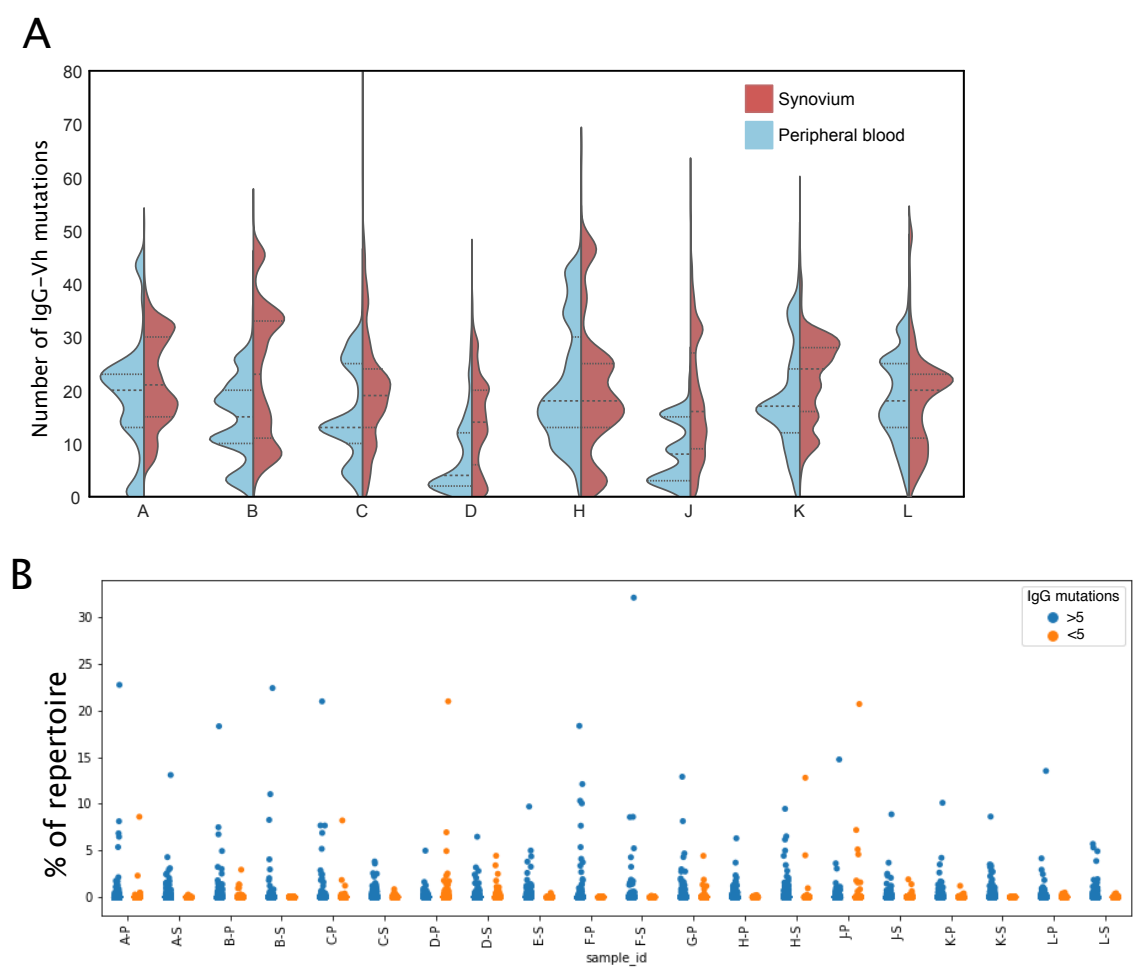

C

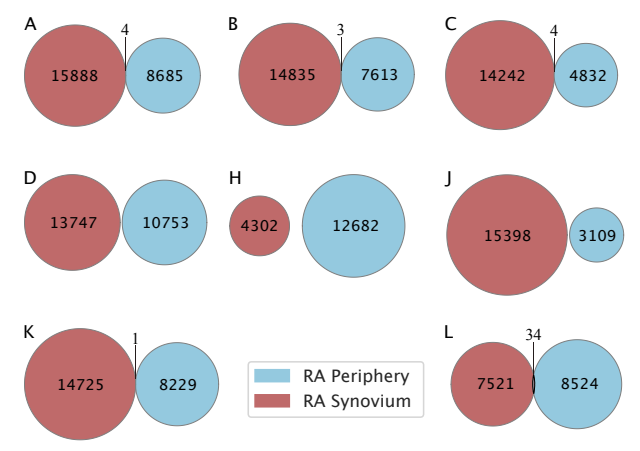

D

i) Patient B Clone 36

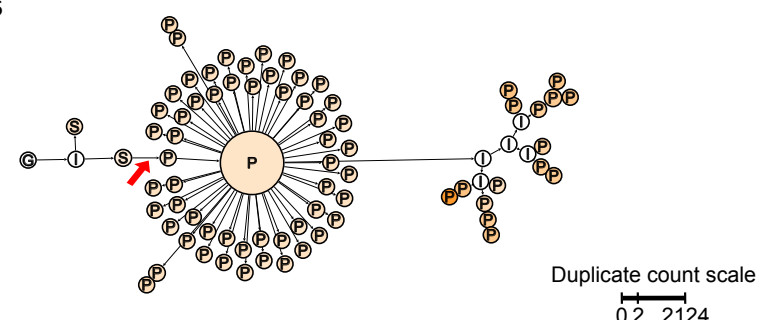

ii)

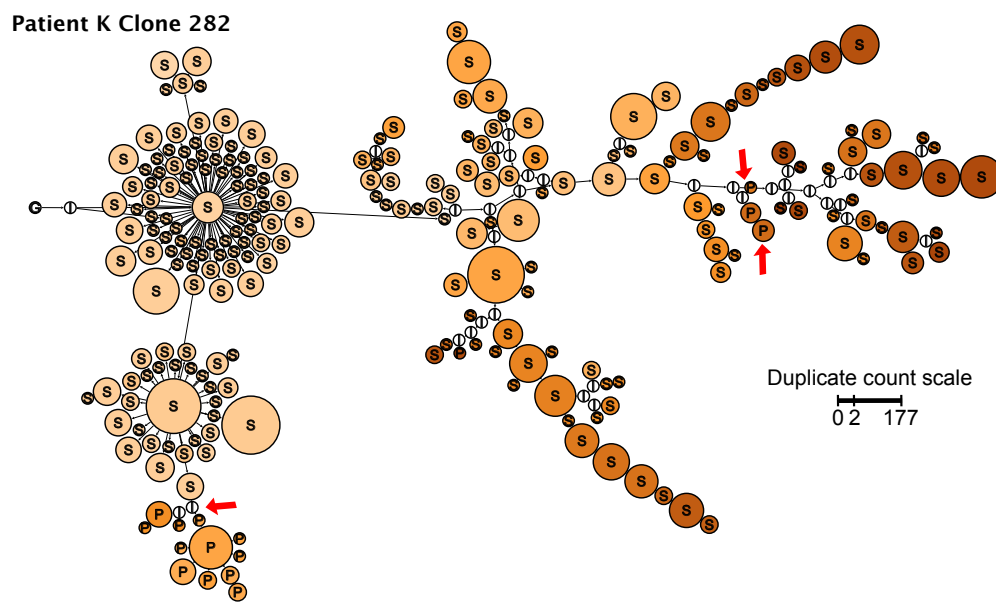

Number of nucleotide mutations

$\begin{array}{llllllllllll}0 & 5 & 10 & 15 & 20 & 25 & 30 & 35 & 40 & 45 & 50 & 55\end{array}$

(G) Germline sequence (P) Peripheral sequence

(D) Inferred sequence Synovial sequence

1 Egression event 